\title{
Sociology of Religion and the Occult Revival
}

\author{
By LENNART EJERFELDT
}

"The postwar growth of new, exotic, and esoteric religions and quasireligions widely identified as cults reached such a peak in the late 1960s, invading even the university itself, that the study of such phenomena could finally be accepted as an object of legitimate academic endeavor."' This "academic endeavour", or more precisely the encounter of sociology of religion with the occult revival is the subject of this survey.

In the public debate many have been inclined to look at the occult revival only as a commercial gadget or a popular fad. If so, it would be a subject for the media researchers or the market psychologists. Even the social scientists have emphasized this "consumer" aspects of modern occultism, but have not seen this as the essential part of the movement.

We are not here pre-occupied with the religio-historical or psychological aspects of the occult revival. ${ }^{2}$ The "new" that makes the cults of the occult revival to "new religions" of the Western world, is their recently increased social significance. Historically most of modern occultism is anything but new. Astrology counts its age in thousands of years as do the I Ching oracles, modern spiritualism has its beginning in the middle of the 19th century; many modern cults derived from the New Thought tradition have its roots in the same age. Eastern wisdom in theosophical shape has been among us since the last quarter of the last century and Rosicrucianism, with obscure origines in the beginning of the 17th century, also got its modern form in late 19th.

Really new is the cult connected with belief in Flying Saucers and some quasi-scientific and "mystagogic" forms of occultism. ${ }^{3}$

\footnotetext{
1 Wallis $1974 b, 299$.

${ }^{2}$ Only works immediately dealing with the sociology of the occult revival will be considered in this review; neither general treatments of occultism nor of sociology of religion.

${ }^{3}$ Good expositions in Buckner, $223 \mathrm{ff}$, and in Wallis $1974 a, 27 \mathrm{ff}$.
} 
As a point of departure is chosen an often cited text by Andrew Greeley, originally published in Social Research 1970. Greeley sees in the occult revival a sort of regression, "the return of the tribal gods". These "gods" or dimensions of the movement are labelled "superstition" "ecstasy" and "tribal consciousness" or "groupism". Superstition is astrology, ritual magic, I Ching, witchcraft; ecstacy, according to Greeley, is the effort to break out of the every day reality to establish contact with the "primordial force" of universe, be it through drugs, music or religious enthusiasm of more conventional art, "mystical" or "charismatic".

Groupism is the "quest for community". Intentional communities communes, tribes or whatever called, are a distinctive trait of the occult revival. ${ }^{4}$

These three dimensions or orientations of the occult revival can exist together or separately. Superstition often appears without ecstacy or groupism, because it usually is the least demanding and the most "consumer" oriented. Many types of groupism lack any basis in a common spiritual or religious ideology. But ecstacy is mostly based on beliefs, that could be designated superstitious and are collectively expressed.

From the research and theorizing about the occult revival we have picked up some main themes. The first is the social diffusion of the new occultism. In this field, we find some studies of superstition, especially astrology. These illuminate the differences in social connotation between the consumers of superstition and the followers of institutional religion.

Secondly the study of the occult revival has made valuable contributions to the conceptualizing of "cult" and the cultic phenomenon. Thirdly, we will look upon the connection between the occult revival and the counterculture. The problem of the rise of cults as a symptom of socio-cultural change will be briefly discussed with reference to Bell's thesis of "the disjuntion of culture and social structure'. Lastly, we proffer some reflections on the occult revival and the new spiritual trends in the churches, which so sharply contrast with the theology and churchmanship of the sixties.

Most rewarding are a couple of French poll research studies on the consumption of astrology and the use of other forms of divination. In 1963 the IFOP Institute interrogated a sample of the French people of their knowledge of the own zodiac sign, horoscope-reading and whether they believed in it, at least partly. $30 \%$ could be regarded as astrology consumers. The

${ }^{4}$ Cf. Greeley, 205 ff. 
woman percentage was nearly the double of that for men, but in all other respects the "modern" distribution pattern was obvious. Among occupational categories "clerical and sales" was the most astrology-prone, $46 \%$, with manual workers, $30 \%$, and farmers and farm hands, $15 \%$, at the bottom of the scale. The percentage consumers steadily rose with size of locality and regularly declined with age.

Differences among occupational groups and domicile may to some extent be explained by reading-habits, but that is no explanation for the great differences among age classes. ${ }^{5}$

A study in 1967, conducted by IRES-Marketing, asked similar but not the same questions, and the results were quite the same in respect of occupation, locality and age. The same questionnaire asked also regarding consulting some sort of diviner, card reader, clairvoyant or other person predicting the future. The positive answers were $12.5 \%$ and again, within this more restricted group, the occupational categories ranked in the same order. Also regional differences were elucidated, with the Paris region and the Riviera at the top, the Center and Lyon regions at the bottom. The higher propensity of the young to visit a sooth-sayer is demonstrated by the fact that already in the age group 26-30 the same proportion as among older people had made such a visit. ${ }^{6}$

The IFOP study exhibits the atheists to be most adverse to astrology. The practizing Catholics were average astrologyconsumers, while causal conformists were the most avid. Superstition in the form of astrology or other divinations obviously is compatible with a "religious" orientation, but a closer identification with the church has the opposite effect.

The same theme is treated in quite another sort of study on superstition and religion. Four students made a small scale research in the London suburb of Islington and published their findings in $1970 .{ }^{7}$ The size of the poll was so small that the results say very little about the spread of the attitudes and beliefs investigated in England, London or even Islington. What is valuable, and probably reliable, is the relationship they discovered between superstition and religion.

A set of questions provided the researchers with an index of "supersti-

5 Cf. Maitre, $429 \mathrm{ff}$.

${ }^{6} \mathrm{Cf}$. Defrance, $75 \mathrm{f}, 163 \mathrm{ff}$.

${ }^{7} \mathrm{Cf}$. Abercrombie, $94 \mathrm{ff}$. 
tiousness", a serious interest in astrology, belief in premonitions, in ghosts or spirits that could be seen or sensed, and visits to a palmist, fortune-teller or astrologist. According to the number of positive answers $18 \%$ were classified as "very superstistitious", $24 \%$ as "quite superstitious" and 24 , and $30 \%$ respectively as "quite" and "very unsuperstitious".

Questions about the belief in God, in after-life, the importance of religion in ones life, private prayers and belief in their efficacy permitted the respondents in the same way to be ranked according to "religiousness". $33 \%$ answered that religion was "very" or "fairly" important to them. The other positive answers had a higher positive percentage, and about one third could be regarded as "religious", so defined. Women were more religious than men. Middle class women were markedley more religious than workingclass, while the class differences among men were insignificant, though the age factor was more important.

The "purpose of constructing these groups was to estimate the extent to which the religious minority overlaps with the superstitious minority". ${ }^{8}$ Such an overlapping proved to be the case.

The religious third were evenly distributed between the "superstitiousness" groups, while the non-religious clustered in the "nonsuperstitious" groups. Or the other way round: one half of the "very superstitious" were religious, but only one fourth of the very unsuperstitious". The relationship between religion and superstition held for both sex and class groupings.

But when another criterion of religiousness was introduced in the analysis, the relationship was suddenly reversed. The church-goers appeared to be a very special sub-group within the religious minority. They were less superstitious than those who never attended, and of the weekly attenders, $58 \%$ fell in the "very unsuperstitious" group. Nearly a quarter of the unsuperstitious went to church at least once a month, but only $5 \%$ of the very superstitious.

This completely reversed relationship even proved to hold for sex, class and age. The most plausible explanation is, according to the authors, that the church exercises a genuinely countersuperstitious influence among its adherents. 9 "Moreover, we have some evidence that for those people who

\footnotetext{
$8 \mathrm{Ib} ., 111$.

${ }^{9}$ Cf. ib., 113.
} 
do not go to church but say they are religious and often pray, religious belief has moved quite far from the orthodox church position and is really much closer to what would normally be called superstition."10

Comparisons between studies as different in size and aim as the French and the English one are of course difficult. One difference seems to be repudiation of astrology among French workers, that has no correspondence in Islington. But the inquiries are in agreement about the correlation between religion and superstition. The atheists and the church-oriented religious are the least superstitious, while those diffusely or privately religious in between are the most likely to be superstitious.

Some hints of the relationship between religion and superstition is also to be gathered from Mol's investigation on religion in Australia. 13\% of the total admitted that they at least sometimes follow the guide lines of their horoscope, but the percentage among roman Catholics and among regular church-goers of all confessions sank to 9. Rather than was the case in France or London, those in Australia declaring themselves to have no religion, were markedly more prone to follow the stars, $19 \% .{ }^{11}$

These studies all have certain consequences for the debate on secularization. The regress of institutional religion has given way not only to more "rational" world views, but also to superstitious beliefs and practices.

In the field of religious organizations, the occult revival mainly gives rise to cults. In the church-sect typology, the cult represents a more loose organization, often of a limited lifespan, is dependent on a charismatic leader and deviates in a marked manner from religious or scientific "orthodozy".

The occult movement has also brought about some new departures for the conceptualizing of cult. The cults are no longer a purely marginal phenomenon, and the focus of interest has moved from the particular cults and the cult as a type of religious organization to "the cultic".

This tendency is amply illustrated by Colin Campbell in an essay, where he puts forward the concept of "the cultic milieu" 12 . He notes that the individual cults tend to succeed quickly or to take on the characteristics of sects. But he finds rather doubtful if the correct strategy for the develop-

\footnotetext{
10 Ib., 124.

${ }^{11}$ Cf. Mol, 43.

12 Campbell, $121 \mathrm{f}$.
} 
ment of a genuine theory of the cultic phenomena is to follow the proceedings used in studying sects. Cults are quite different with their blurred boundaries and fluctuating belief systems.

Campbell admits that the cultic groups are ephemeral and unstable, but that there is a continual process of cult formation. Therefore, cults must exist within a milieu which, if not conducive to the maintenance of individual cult, is "clearly conducive to spawning cults in general". ${ }^{13}$ This cultic milieu includes all those beliefs and practices we have labelled occult.

A common cause for the spokesmen of various cultic movements is their hostility against "orthodoxy", though towards each other, they are syncretistic and "ecumenical". The cultic milieu is, according to Campbell, kept alive by a common "communication structure": magazines, bookshops etc. Essential for the cultic milieu is the common ideology of "seekership". This seekership puts pressure on cults to expand, to explore new cultic regions.

There is often a differentiation between the cult proper and the society of seekers. Beside the categories of "adherents" and "seekers", a third party can readily be recognized: the "consumers" of the products of the cultic milieu.$^{14}$ This is obviously where the exploitation in the media of the occult revival comes in.

Campbell gives a list of functions of the cultic milieu. It can work as an agency of cultural diffusion of alien cultural items, as an agency of cultural innovation through the process of syncretization. It is a sort of "gene pool" enhancing the society's potential for cultural mutations, and it could perhaps also act as a source of renewal for ailing "orthodox" belief systems. ${ }^{15}$

The last part of Campbell's essay consists of a discussion of the cultic milieu and secularization. Viewed as the decline of power and influence of the institutional religion caused by structural changes, secularization has been to the advantage to the cultic milieu. But secularization can also be "culturally" or "intellectually" interpreted as the advance of rationalism and emphasis purely on this world. In this perspective, a scientific world concept should have displaced religious belief. If so, the tendency to secularization ought to have even less difficulty in overcoming the heterodox versions prevailing in the cultic milieu.

\footnotetext{
${ }^{13}$ Cf. ib., $128 \mathrm{f}$.

${ }^{14}$ Cf. ib., $129 f$.

${ }^{15} \mathrm{Ib} ., 135$.
} 
But Campbell sees the outcome of the clash between the occult revival and the "cultural" secularizing forces as far from sure: "Ironically enough, therefore, it could be that the very processes of secularization which have been responsible for 'cutting back' of the established form of religion have actually allowed 'hardier varieties' to flourish, or possibly created the circumstances for the emergency, not of a secular scientific society, but of a society centred on a blend of mysticism, magic and pseudoscience."

Edward Tiryakian has proposed concepts of similar significance. To carry the sociological interpretation of the occult further, he points to the need of a more articulated conceptualization. In particular, he is interested in the relationship between occultism and socio-cultural change.

For this analysis he uses three terms: "occult", "esoteric" and "secret society". "Occult" refers, in Tiryakian's terminology, to the practices and procedures "which draw upon concealed forces of the universe". "Esoteric" is the religio-philosophical belief underlying such occult practices, and "esoteric knowledge" is, by definition, concealed from public dissemination.

Therefore, the handling and transmission of all this requires "secret societies". Typical for secret societies are rites of initiation and the conception of an elite of "Magi"' or "Grand Masters". . $^{16}$

Tiryakian discusses in a historical perspective the importance of esoteric culture and secret societies in regard to socio-cultural change. Along with other observers, he notes the affinities of to-day's esoteric culture with the importance of occult knowledge in the Renaissance epoch. ${ }^{17} \mathrm{He}$ also points to the fact that many new scientific insights have had a pre-history as esoteric knowledge, e.g. Messmer's animal magnetism as a precursor of hypnotism and more indirectly of psychoanalysis.

The conclusion of his essay reads: "If we come to perceive the occult revival of today not as en ephemeral fad of mass society but as an integral component in the formation of a new cultural matrix, [...], as an important vehicle of collective representations of social reality, we will see the Age of Aquarius as a major sociological happening." 18

In a recent contribution Wallis has returned to the problem of cult as an

\footnotetext{
${ }_{16}$ The historical analogies between the Renaissance (ritual magic, witchcraft, hermetism, belief in prisca theologia) and the occult revival are well exposed in Nugent, $72 \mathrm{ff}$.

${ }^{17}$ Cf. Tiryakian, 510.

${ }^{18} \mathrm{Cf}$. Wallis $1974 b, 306 \mathrm{ff}$.
} 
organization, but with Campbell's concept of the cultic milieu as a departure.$^{19} \mathrm{He}$ is particularly interested in the development of cultic movement, and he has previously made studies of Scientology (an example of transition from cult to sect) and of the "mystagogic" Aetherius Society. ${ }^{20}$

The individual cult, emerging from the cultic milieu, faces certain difficulties due to its syncretistic and eclectic character. "The problem of doctrinal precariousness" has to do with the distance from the cultic milieu, that has to be sufficient to provide the cult with an own profile. "The problem of authority" has its roots in the seekership and the service-mindedness of the cult, and "the problem of commitment" is related to the high turn-over caused by the same factors.

Wallis suggests that the cultic movements have recourse to two basic strategies to meet these difficulties. They can either take the form of "spontaneous cults", dependent on the leader's special charisma, without any attempts to centralize authority organisationally, or be "centralized cults", where leaders try to institutionalize their authority. According to Wallis this last category is already on its way to sectarianism and in fact an embryonic sect. $^{21}$

A rather different evaluation of the occult revival from that of Campbell and Tiryakian has been put forward by Marcello Truzzi. In an essay on definitions and dimensions of the occult, he has endeavoured to construct a typology. His types of occultism are (1) proto-scientific (parapsychology), (2), quasi-scientific (astrology), (3) pragmatical (magical practices), (4) shared mystical (Transcendental Meditation), (5) private mystical (messages from mediums or extra-terrestrials). ${ }^{22}$

Such a division can be helpful, but Truzzi uses it to try to "unpack" the term occult itself and dissolve it in various components. Another essay looks upon the occult revival as popular culture. Here Truzzi wants to see the occult revival as an indication of secularization. The inclusion of witchcraft or satanism as themes in the popular culture demonstrates their lack of awe-inspiring charge, and therefore they are "secularized". He refers to the mass version of occultism as "pop religion", but he adds that this is ade-

\footnotetext{
19 Cf. Wallis $1974 a, 27 \mathrm{ff}$.

$20 \mathrm{Cf}$. Wallis $1974 b, 325 \mathrm{ff}$. He is arguing against Nelson, $152 \mathrm{ff}$, who on the basis of his research on spiritualism tried to show how cults developed to religions.

$21 \mathrm{Cf}$. Truzzi $1972 a, 637 \mathrm{f}$.

${ }^{22}$ Cf. Truzzi $1972 b, 28 \mathrm{ff}$.

14-752446 H. Biezais
} 
quate only for the mass version, not for its significant minority of serious followers. ${ }^{23}$

Basically Truzzi seems to be at odds with Campbell or Tiryakian but on closer examination, much of the difference appears to be due to whether one looks at it from the point of view of the "adherent" or from that of the "consumers".

A considerable number of books on the new cults has been published during the last few years. By far the most valuable, both from a sociological and a historical point of view, seems to be that of Ellwood. Religious and Spiritual Groups in Modern America is an inventory and a classification of small religious groups, but contains also a very sane discussion of modern cultic phenomena.

Ellwood makes use of the classical juxtaposition of "emissary" and "exemplary" religion. Predominant in the Western world has been the first in the mainstream of Judeo-Christian tradition, with its emphasis on the mission and the message. The "exemplary" religion is that of gurus and wisdom teachers, and it is an alternative religious tradition now come to the fore in the occult revival. ${ }^{24}$ Ellwood's general characterization of cult is rather in accordance with other attempts. What is new in his approach is the way Ellwood elaborates the "shamanistic" elements in modern cults: the supernatural experiences of the founder or leader, the interpretations of certain experiences as marvellous travels, supernatural helpers and the emphasis on healing and psychic powers.

The occult revival is closely linked to the counter-culture, or the modes of thought and behaviour which developed among younger people, especially in America, in the 1960s. Of course, it had a pre-history in the beat generation and the drug romanticism. In the sixties the counterculture was both a potential revolutionary political force-the New Left-and an experimentation with lifestyles beside or beyond the society in general. The student revolt, in the political sense of the term, culminated around 1968, and since then the shift of emphasis to the mystical and occult has been obvious. In the summer of 1974 , one could read in the radical magazine Ramparts a

\footnotetext{
${ }^{23}$ Cf. Ellwood, 24. Cf. Evans with the emphasis on scientology, Flying Saucerians and Black Boxes, $116 \mathrm{ff}, 137 \mathrm{ff}, 179 \mathrm{ff}$. Cf. Needleman, especially $22 \mathrm{ff}$, on the Eastern cults.

${ }^{24}$ Cf. Ellwood, $28 \mathrm{ff}$.
} 
heartbreaking account of the militant leaders of the student revolt today flocked around various gurus. ${ }^{25}$

In same rare cases, the literature of the counter-culture itself is of considerable sophistication and brings valuable contributions to its interpretation. While Theodor Roszak previously has produced an understanding chronicle of the making of the counterculture his book, "Where the Waste Land Ends" must be regarded as a major tract by a true believer. Roszak is eclectic. His principal authority is not found among the Eastern sages, but in the prophetical mysticism of William Blake. A typical passage: "We are in for an interlude during which an increasing number of people in urbanindustrial society will take their bearings in life from I Ching and signs of the zodiac, from yoga and strange contemporary versions of shamanic tradition. The quest for communal reality assumes the shape of a massive salvage operation, reaching out in many unlikely directions. I think this is the great adventure of our age and far more humanly valuable than the race for space! It is the reclamation and the renewal for the Old Gnosis." 26

The connections between the occult revival and the counterculture is perhaps most obvious in the "communal" movement, what Greeley called "groupism" and "tribal consciousness". The founding of communes have had a high tide in America since the middle of the 1960s, often compared with the Golden Age of utopian colonies, the 1840s.

Out of the ample literature on the subject, two books may be selected as being especially clarifying. The sociological dimensions of the communal commitment have been treated by Rosabeth Moss Kanter, who also makes a comparison between religious and other communes." ${ }^{27}$ More oriented to the history of ideas is Laurence Veysey's huge volume "The Communal Experience", the second part of which is dedicated to contemporary "communities of discipline", some Vedanta monasteries and a commune in New Mexico, partly based on the ideas of Gurdjieff. Veysey's exhibition of the anarchist and mystical trend in the "communal experience" facilitates the understanding of the passing over from political radicalism to occultism in the counter-culture. ${ }^{28}$

\footnotetext{
25 Cf. Kopkind, 26 ff.

26 Roszak, 262.

.27 Cf. Kanter, Rosabeth, $111 \mathrm{ff}$. Critical assessment of Kanter and other recent works on communes in Pitts, $351 \mathrm{ff}$.

${ }^{28}$ Veysey, especially $207 \mathrm{ff}$ and $411 \mathrm{ff}$.
} 
Outside America, the Scottish Findhorn community, with its peculiar mythology, has been the object of a sociological study. ${ }^{29}$

The role of the occult revival in long-range social change has been treated by the well-known sociologist and futurologist Daniel Bell. In 1971, he published an essay on "Religion in the Sixties", indicated to be a part of a forthcoming work on "The Disjunction of Culture and Social Structure". Bell is inclined to see the secularization hypothesis and the radical theology of the sixties as a testimony to this disjunction. The theologians were part of the "culture", the articulate elite, while their parishioners lived in "the social structure". This estrangement between religious leaders and their congregations must lead to the erodation of theology and the breaking-up of the institutional frame-work of religion, and "where religion fails, cults appear'. ${ }^{30}$

In the future, Bell predicts "the multiplication of charismatic sects which are disruptive not only of the religious but of the civil order as well". Religion is no longer looked upon by the "enlightened" culture as an enemy, but "as a means of attacking the institutional order, and as a mode of creating new primordial forms of community and symbolic experience, which become substitutes not only for traditional religion, but for society as well".

In the last chapter of his new book, "The Coming of Post-Industrial Society", Bell returns to the same theme and tries to demonstrate that the disjunction is inherent in today's liberalcapitalist society. This society has necessitated mass production and mass consumption and to this end promoted a hedonis tic way of life, that has destroyed the very basis of capitalist society, the Protestant ethic. The culture is the bearer of this hedonistic world view and is now revolting against the dominant social structure. This "adversary culture" was in the 19th century "private and hermetic", today it is "public and ideological". Bell views the occult revival as a consequence of socio-cultural change and as a deadly danger to Western society. (Although, in other respects, he has a great confidence in technological progress. $)^{31}$

The new trends in Christian spirituality, the charismatic revival and the

\footnotetext{
${ }^{29}$ Cf. Rigby, $74 \mathrm{ff}$.

${ }^{30}$ Bell 1971 , especially 456 and 474 . Here is not the place to discuss if those church leaders were "theologically" wrong, but most certainly they were "sociologically" quite mistaken.

${ }^{31}$ Cf. Bell 1973, 477, 480.
} 
meditation movement, must certainly be considered in connection with the occult revival, to some extent as due to the same influences, but partially as a reaction against it. Some sociologists, such as Robert Nisbet, take the view that the new evangelical awakening is a more pervasive phenomenon than the occult revival. "Religion in this form and substance can quench more easily than anything else the desperate thirst for communal membership that is rooted in emotion and feeling and that can be seen spreading in contemporary political-bureaucratic societies around the world. ${ }^{32}$

The evalutions of the occult revival, both regarding its significance and its positive or negative influences, have varied among the sociologists quoted here, but most of them seem inclined to consider, as does Tiryakian, the Age of Aquarius to be a major sociological happening.

\section{Bibliography}

Abercrombie, N. et al., 1970, Superstition and Religion: The God of the Gaps. A Sociological Yearbook of Religion in Britain 3.

Bell, D., 1971, Religion in the Sixties. Social Research 38,3.

- 1973, The Coming of Post-Industrial Society. London.

Buckner, H., 1968, The Flying Saucerians: An Open Door Cult. Sociology and Every Day Life. Englewood Cliffs.

Campbell, C., 1972, The Cult, the Cultic Milieu and Secularization. A Sociological Yearbook of Religion in Britain 5.

Defrance, P. et al., 1971, Le retour des astrologues. Les Cahiers de Club du Nouvel Observateur. Paris.

Ellwood, R., 1973, Religious and Spiritual Groups in Modern America. Englewood Cliffs, N.J.

Evans, C., 1973, Cults of Unreason. London.

Greeley, A., 1970, Superstition, Ecstacy and Tribal Consciousness. Social Research 37,2.

Kanter, Rosabeth, 1972, Commitment and Community. Cambridge, Mass.

Knox, R., 1950, Enthusiasm, Oxford.

Kopkind, A., 1974, Mystic Politics. Ramparts July.

Maitre, J., 1968, La consommation d'astrologie dans la France contemporaine. La Divination 2. Paris.

Mol, H., 1971, Religion in Australia. Melbourne.

Needleman, J., 1970, The New Religions. New York.

Nelson, K., 1969, The Spiritualist Movement: A Need for the Redefintion of the Concept of Cult. Journal for the Scientific Study of Religion 8,1.

Nisbet, R., 1973, The Quest for Community. Dialogue 6,4.

Nugent, D., 1971, The Renaissance and/of Witchcraft. Church History 40,1.

\footnotetext{
${ }^{32}$ Nisbet $25 \mathrm{f}$. The new trends in the churches closely correspond to the tendencies which Knox $581 \mathrm{f}$, twentyfive years ago described as "evangelical enthusiasm" and "mystical enthusiasm". He treated these phenomena historically and had no idea of a massive reawakening.
} 
Pitts, Jesse, 1973, Survey Essay on Communes. Contemporary Sociology 2,4.

Rigby, A. \& Turner, B., 1972, Findhorn Community, Centre of Life: A Sociological Study of New Forms of Religion. A Sociological Yearbook of Religion in Britain 5.

Roszak, T., 1972, Where the Waste Land Ends. Politics and Transcendence in Post Industrial Society. New York.

Tiryakian, E., 1973, Toward the Sociology of Esoteric Culture. American Journal of Sociology 78,3 .

Truzzi, M., $1972 a$, The Occult Revival as Popular Culture: Some Random Observations on The Old and the Nouveau Witch. Sociological Quarterly 13.

- $1972 b$, Definition and dimensions of the occult; towards a sociological perspective. Journal of Popular Culture 4.

Veysey, L., 1973, The Communal Experience. Anarchist and Mystical Counter-Cultures in America. New York.

Wallis, R., 1974 a, The Aetherius Society: a Case Study in the Formation of a Mystagogic Congregation. The Sociological Review 22,1.

- $1974 b$, Ideology, Authority, and the Development of Cultic Movements. Social Research 41,2 . 